\title{
Heavy Metals Bioaccumulation Capacity on Marine Algae Biomass from Romanian Black Sea Coast
}

\author{
EMIN CADAR ${ }^{1}$, RODICA SIRBU ${ }^{1 *}$, BOGDAN STEFAN NEGREANU PIRJ OL ${ }^{1}$, ANA MARIA IONESCU른 ${ }^{2}$ TICUTA NEGREANU PIRJ OL ${ }^{1}$ \\ ${ }^{1}$ Ovidius University of Constanta, Faculty of Pharmacy, 124 Mamaia Blvd., 900527, Constanta, Romania \\ ${ }^{2}$ Ovidius University of Constanta, Faculty of Medicine, 124 Mamaia Blvd., 900527, Constanta, Romania
}

\begin{abstract}
Knowledge of environmental pollution with an impact on health is essential for a sustainable environment and useful for people. The coastal areas of the world's seas and oceans are polluted with different pollutants from technological sources and from other sources of socio-human activities. The pollutants studied are heavy metals $\mathrm{Cd}, \mathrm{Cu}, \mathrm{Zn}$ and $\mathrm{Pb}$. In the paper are presented researches regarding the heavy metal concentrations determined in samples from marine water, sediments and algal mass, harvested from six stations from different areas of the Romanian Black Sea in two different years 2017 and 2018. The analyses were performed in the Chemistry Laboratories of the Faculty of Pharmacy, Ovidius University in Constanta, by a spectrophotometric method using Atomic Absorption Spectrometer ContrAA-700, Analytic Jena AG. For marine water in 2018 the following concentrations were obtained: $\mathrm{Zn}>\mathrm{Pb}>\mathrm{Cu}>\mathrm{Cd}$ and in 2017 the order was different: $\mathrm{Zn}>\mathrm{Cu}>\mathrm{Pb}>\mathrm{Cd}$. For sediments in 2017 the order of concentrations is $\mathrm{Cu}>\mathrm{Zn}>\mathrm{Pb}$ $>\mathrm{Cd}$ and in 2018 the highest values in the sediment are recorded by the next high values $\mathrm{Cu}>\mathrm{Pb}>\mathrm{Zn}>$ $\mathrm{Cd}$. Constant climate change and increased eutrophication in recent years have led to a massive increase in marine biomass in the Black Sea. For seaweed samples there are accumulations in the order of $\mathrm{Zn}>\mathrm{Cu}>$ $\mathrm{Pb}>\mathrm{Cd}$ in both years. Bioaccumulation factors in water $B C F_{\text {watr }}$ were higher in algae for $\mathrm{Zn}$ and $\mathrm{Cu}$. From the analysis of bioaccumulation factors, it can be noticed that seawater algae accumulate heavy metals from seawater and sediment (confirmed by $B C F_{\text {water }}>1$ or BCF $>1$ ). The accumulation of heavy metals in seaweed shows the existence of pollutants and marine pollution factors. Marine algae are the best biomarkers of pollution.
\end{abstract}

Keywords: polluting agents, bioaccumulation factor, heavy metals, spectrophotometric method, marine sediments.

Sustainability has become a broad term that can be applied in almost every aspect of life on Earth, locally or globally and at different times. Coastal marine waters contain pollutants that can affect both the marine environmentand human health. The capitalization of Black Sea marine resources is conditioned by the negative impact of pollutants. The Black Sea is a great resource due to its geographical position in relation to the planetary Ocean, the character of semi-closed, a huge catchment area, as well as its unique hydro-biological features make the Black Sea a highly sensitive ecosystem, exposed to pollution [1]. Changes in the parameters of the physical, chemical and biological agents of the Black Sea is due to the anthropic impact on the entire basin, and eutrophication is hastened by the vast quantities of biogenic sources offered by the Danube, the Dnieper and the Dniester $[2,3]$. With increasing human population, pollution has become a great concern. Pollution from human activities is a problem that does not have to be inevitable [ $4 \div 6$ ]. Contamination with pollutants can be found in both fish species and marine flora of coastal waters or of major tributaries such as the Danube for the Black Sea [7]. These important purposes have led to the need for taking into account legal aspects regarding protection against polluting agents from the Black Sea, which may contaminate marine bioresource [8]. With a comprehensive pollution prevention program, most pollution can be reduced, reused, or prevented. Reducing and managing pollution may decrease its health impacts [9]. The capitalization of Black Sea marine resources for therapeutic purposes is conditioned by the quality of maritime habitats [10]. The Black Sea ecosystem has been studied in order to assess the opportunity of marine resource harnessing [11, 12].
Important attention has been given to algae that can be harnessed, as these represent an important resource in the medical and pharmaceutical fields [13-15]. It is well known in toxicology that there is a need to evaluate the impact of polluting agents that are accidentally released in the marine ecosystem, bioaccumulation being related to the fact that living organisms can retain toxic substances at a higher rate than they can be removed due to metabolic activities [16]. Heavy metals are the main polluting agents in the marine environment, as they are easily assimilated and accumulated in living tissues and food webs. Heavy metal bioaccumulation in aquatic foods does not only threaten biodiversity, but it can also directly impact human health [17]. Modern means of evaluating risk compare noxious substance concentrations in water and contaminated tissues [18]. Under current European Union legislation, any chemical product that has wet mass with a bioconcentration factor BCFw $>1$ is considered to have an accumulation potential and thus regarded as noxious for the aquatic environment and food webs [19]. According to the Strategy for marine environment framew ork directive [8], Romania is required to provide information needed to develop a measurement program which can allow for a good ecological state of the marine ecosystem until 2020 [20]. Bioaccumulation is a topic that has been frequently approached lately by the environment research and risk analysis field due to the fact that it represents organism exposure to various environmental polluting agents. The last decade has proven that chemical substance bioaccumulation and bioamplification, through the trophic or food chain, can be a necessary condition in order to outline adverse reactions in species and individuals [21]. 
The bioaccumulation of heavy metals in aquatic food netw orks not only directly threatens biodiversity but also has consequences with an impact on people's health, where people were directly exposed to harmful effects of mercury after eating spotted fish $[22 \div 24]$.

There are numerous factors influencing heavy meal accumulation in living organisms in the aquatic environment. These factors act in different ways, according to the species and the type of metal, such as: $\mathrm{pH}$, various organic compounds, complex particles, the presence or absence of other metals, anion extraction, temperature, saltiness, light intensity, redox potential and diluted oxygen concentrations [25]. Contamination of the aquatic ecosystem due to synthetic organic compounds and heavy metals and their consequences regarding health and maintaining biodiversity are important debate topics among environment scientists [26 $\div 29$ ]. Literature on the matter provides recent studies which outline the existence of heavy metals in the coastal waters of the Black Sea, among which we can quote for the Turkish coast of the Black Sea: for water [30], sediment [31, 32], biota [33], molluscs [34]

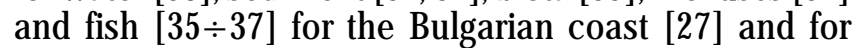
Romanian Coast $[23,38]$. The approach of pollution problems for the Romanian shore has been accomplished through the determination of polluting agents in water, sediment, and organisms [39, 40]. The purpose of this research has been to study heavy metals contents in sea water, sediments and marine algae (relevant species at different trophic levels, representative for shallow waters) from the Romanian Black Sea shore habitats. Based on the results obtained, the bioaccumulation factor was recognized from heavy metal concentrations in water and sediments. In order to evaluate marine environment quality regarding heavy metals concentrations (costal area), several of the polluting sources were established and experimental determinations of heavy metals concentrations in water, sediment, and biota (algae) were performed. These coastal ecosystems are directly threatened by a diverse matrix of polluting agents, generated by the municipal residual water treatment plant and diverse sources. Heavy metal concentrations analysed in this study ( $\mathrm{Cu}, \mathrm{Pb}, \mathrm{Cd}$, and $\mathrm{Zn}$ ) were used to calculate BFC. This study enables a better monitoring of heavy metals pollution levels in Romanian Black Sea coast habitats (water, sediments, and biota) and allows for comparisons with other studies in the Black Sea area.

\section{Experimental part}

Plant materials

Sampling sites

The current study monitors heavy metals concentration in seawater, sediments, and sea algae in different harvesting sites in the South region of the Romanian shore. We have chosen the South region of the Romanian shore because it is the most sought after area by tourists, due to its wide beaches, beneficial to human health. Analysis samples were harvested from 6 areas, named S1 through S 6: S 1 - Mamaia North, S 2 - Constanta Casino, S 3 Constanta - harbour, S 4 - Eforie South, S 5 - Costinesti, S 6 - Mangalia harbour. The Rompetrol refinery and the exploitation of sea petroleum resources near Constanta, as well as the industrial residual water treatment plant are important pollution sources with an impact on S 1, S2, and S3. Transportation activities on the Danube-Black Sea canal, the municipal wastewater treatment plant as well as harbour and touristic activities have a polluting impact on S 3, S 4 and S6. For the Constanta and Mangalia harbours, the main accidental pollution sources are related to the functioning of the ships that have access to harbour areas. The samples were collected during July-August in 2017 and 2018, when algae reach maturity and industrial and human activities reach their maximum. Water, sediment, and algae samples originate from the Romanian shore with a depth between 0 and 5 metres.

Determination of heavy metal concentration in seawater: It was particularly important to abide by sampling procedures and to ensure a storage method so as to avoid new, external contaminations. Water, sediment and algae samples were conserved and prepared before preliminary analysis by using the recommended standard methods [41, 42]. In order to determine the total heavy metal content (represented by the metal concentration in an unfiltered sample, which was treated with a mineral acid), water samples were harvested from the surface of the seawater from the established monitoring stations through the use of harvesting devices. Immediately after sample harvesting, without prior filtration, samples were transferred to storage in plastic bottles (polyethylene, polypropylene). Water samples were acidified with ultrapure azotic acid ( $1-5 \mathrm{~mL}$ of $\mathrm{HNO}_{3} / 1 \mathrm{~L}^{\circ} \mathrm{H}_{2} \mathrm{O}$ ) to a $\mathrm{pH}$ of 2 and were kept at $4^{\circ} \mathrm{C}$ before analysis [43]. Due to the high content of salt in seawater, a reduction of analysis interferences was accomplished by changing the seaw ater matrix or through modifying the electro-chemical characteristics of the graphite oven.

Determination of heavy metals concentration in sediments: Special measures were needed in order to avoid any possibility of sediment and algae sample contamination [38]. Sediment samples were initially dried in the oven at $105^{\circ} \mathrm{C}$, then homogenized. Hard materials $(>1 \mathrm{~mm})$, sand, gravel and seashell fragments were eliminated. Mineralization of sediment samples (0.3-0.5 g) was accomplished by adding $10 \mathrm{~mL}$ of azotic acid. Mineralization was performed in three steps ( 5 minutes each) at different temperatures (the first at $140^{\circ} \mathrm{C}$, the second at $160^{\circ} \mathrm{C}$ and the third at $175^{\circ} \mathrm{C}$ ), with the purpose of complete dissolution. After the process, the samples were cooled, filtered through nitrocellulose filtering material in $100 \mathrm{~mL}$ graded flasks, with deionised water.

Determination of heavy metals concentration in marine algae: Algae harvested from the seawater from each of the stations were divided according to type of algae. In order to determine heavy metal content, work procedures were established so as not to contaminate harvested samples.

Preliminary washing and drying: Preliminary washing was performed with seawater, in plastic vats with the help of a shaking device. This operation has the purpose to remove debris, gravel and sand from the prime material. Sea water was preferred because it does not modify the characteristics of the native environment and it avoids cellular lyses, phenomenon which would lead to the loss of organic matter. After washing, the material was settled in order to dry remnant water, in vats with grills. The material was then dried at room temperature. The algae mass has a fragile frame and a chemical and biochemical composition which is affected by temperatures over 50 ${ }^{\circ} \mathrm{C}$.

Grinding and sieving: The dried material was grinded with a ROBOT type grinding device, which is frequently used in the food industry. The device has two working compartments, one from gross fragmentation and the other for fine grinding. The resulting material was separated after granulation with a vibration device for granulometric sieves. The devices has a $0.045 \div 6.3$ set of sieves. Fractions over 1 $\mathrm{mm}$ were once again grinded. From the obtained algae 
powders, 50g from each species were collected for determinations. The analysis method is based on atomic absorption spectrometry which uses the acetylene flame technique (HR-CR AAS-Flame) for the analysis of samples in which concentrations are expressed as $\mathrm{mg} / \mathrm{L}$ (ppm). Atomic absorption spectrometry is one the UV-Vis optical methods and is based on the absorbed radiant pow er of a population of free atoms. Heavy metal concentrations in water, sediment and algae samples were measured using atomic absorption spectrometry methods. The control for AAS methods is represented by: a sample of concentrated acids (with varying volumes, according to the analysed type of sample), subjected to the digestion process. The sample is represented by the following mixture: $2 \mathrm{~mL}$ $\mathrm{H}_{2} \mathrm{SO}_{4} 96 \%, 2 \mathrm{~mL} \mathrm{H}_{3} \mathrm{PO}_{4} 85 \% 2 \mathrm{~mL} \mathrm{HF} 40 \%$ and $1 \mathrm{~mL}$ $\mathrm{HNO}_{3} 65 \%$.

\section{Chemicals}

All used reagents were of analytical reagent grade and were purchased from Sigma-Aldrich, Germany.

Work equipment: The device used High Resolution Continuous Source Atomic Absorption Spectrometer ContrAA-700, Analytik J ena AG, with an auto-sampler for the dilution sample, using acetylene flame technique in for the sequential analysis at specific wavelengths: $\mathrm{Pb}$ $(283.306 \mathrm{~nm}), \mathrm{Cd}(228.8018 \mathrm{~nm}), \mathrm{Cu}(324.754 \mathrm{~nm})$ and $\mathrm{Zn}$ (213.857 nm); Mettler Toledo analytical balance; thermoadjustable electric water bath with a temperature domain of $100{ }^{\circ} \mathrm{C}$; thermo-adjustable oven.

Experiment for the determination of heavy metals content

Solid samples were dried up to $105^{\circ} \mathrm{C}$, in order to reach a constant mass. For mineralization after decantation, the samples were filtered on Whatman quantitative filtering paper. After drying, algae samples were mineralized with concentrated acids in order to determine the presence and concentrations of metallic elements and controlled temperatures and pressures in the digestion system. After completing this process, the content of digestion dishes was introduced in $25 \mathrm{~mL}$ graded flasks and brought to volume with bidistilled and deionised water.

\section{Calibration curves}

For every metal, the calibration curve was established. For each calibration curve, the linear relationship and correlation coefficients are presented ( $r$ ) and $(r)^{2}$, (fig. 1)

Figure $1 \mathrm{a}-\mathrm{d}$ presents the calibration curves registered for $\mathrm{Pb}, \mathrm{Cd}, \mathrm{Cu}$ and $\mathrm{Zn}$ metals and the AAS device detection limits for the four analysed metals. Heavy metals determination was made with the following equation:

$$
\text { [Conc. }]=\frac{C_{\text {curve }} V_{\text {sample }}}{m_{\text {sample }}} m g / k g
$$

The analysed heavy metals were $\mathrm{Pb}, \mathrm{Cd}, \mathrm{Cu}$ and $\mathrm{Zn}$. Bioaccumulation of heavy metals is confirmed when the bioaccumulation factor (BCF) is higher than 1 [39]. BCF represents the ratio between heavy metal concentration in soft tissue and metal concentration in water and sediment. The BCF bioaccumulation factor is defined as:

$$
B C F_{\text {water } / \text { sed }}=\frac{c_{b}}{c_{\text {water } / \text { sed }}}
$$

where $C_{b}$ represented the heavy metal concentration in soft tissue and $C_{\text {water/sed }}$ represents heavy metal concentration in water or in sediment [40]. We calculated $\mathrm{BCF}_{\text {water/sed }}$ for algae.

Forr calculation and statistics we used mean and standard deviation values. The normalcy test was performed using the Shapiro-Wick test followed by comparison of samples using Excel 2013 software and ANOVA followed by Tukey HDS.

Statistical Analysis: All experiments were conducted in triplicate and ANOVA (using SPSS 11.5 statistics) software was used to compare the mean values of each treatment. Significant differences between the means values of parameters were determined by using the Duncan test ( $P$ $<0.05)$.

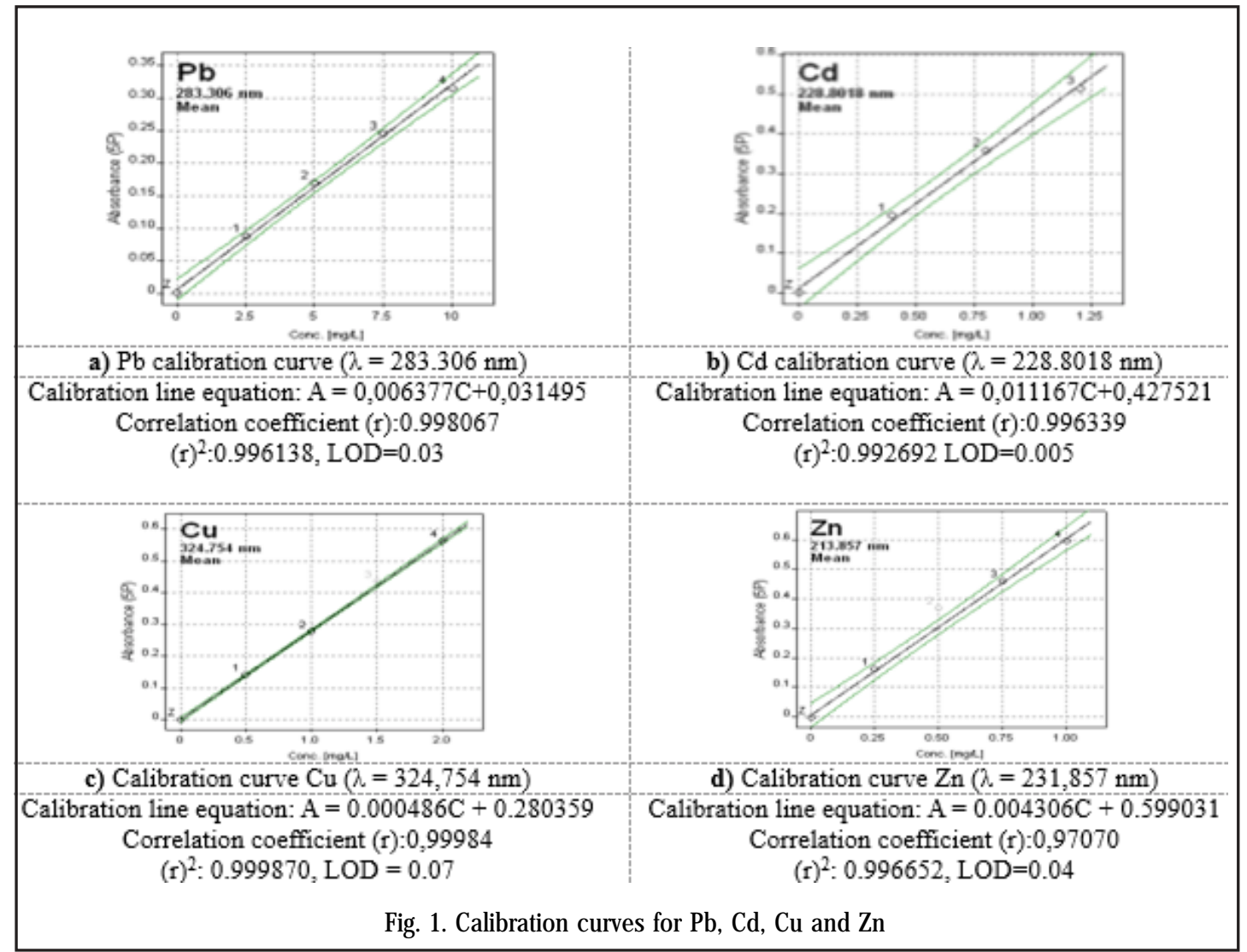




\section{Results and discussions}

Heavy metals in seawater: In order to identify pollution levels on the Black Sea coast, we calculated the mean of concentrations and the standard deviation for each studied metal. Seawater heavy metals concentrations are expressed as mean and standard deviation values for the two years analysed and are presented in Table 1, which takes into account all six harvesting stations. The highest concentration in 2017 was achieved by $\mathrm{Zn}(21.17 \pm 1.0 \mu \mathrm{g} /$ g), followed by $\mathrm{Cu}(16.258 \pm 0.93 \mu \mathrm{g} / \mathrm{g})$ and $\mathrm{Pb}$ in 2016 $(12.93 \pm 0.074 \mu \mathrm{g} / \mathrm{g})$ and in 2018: Zn $(20.12 \pm 0.58 \mu \mathrm{g} / \mathrm{g})$ followed by Pb $(12.78 \pm 0.90 \mu \mathrm{g} / \mathrm{g})$, and $\mathrm{Cu}(11.24 \pm 0.93$ $\mu \mathrm{g} / \mathrm{g})$. The exception is represented by $\mathrm{Cd}$, which registered a slight growth in $2018(0.568 \pm 0.101 \mu \mathrm{g} / \mathrm{g})$ compared to $2017(0.551 \pm 0.07 \mu \mathrm{g} / \mathrm{g})$.

Figure 2 presents the annual variation of mean concentrations of the four heavy metals for each sample harvesting station. Heavy metals from seawater sampled from each station are taken into account. It can be noticed that the highest values are registered by $\mathrm{Zn}$, followed by $\mathrm{Cu}$ and the $\mathrm{Pb}$. Stations S3 and S6 registered the highest values for heavy metals. These stations are situated near harbours, where local activity has a high impact on increasing pollution. Somewhat higher concentrations in stations $S 2$, $\mathrm{S} 3$, and $\mathrm{S} 6$ can be explained by the existence of the commercial and touristic harbour, while for stations $\mathrm{S} 1$, S 4 , and $S 5$, due to the proximity to water waste treatment plants.

Many heavy metals are discharged in the marine environment and chemical contamination is now widespread both on the sediments and on the water. These environmental pollutants have the potential to induce a large range of acute and long-term effects (e.g. endocrine disturbances, immunetoxicity, neurological disorders, cancers, others diseases) on human health and ecosystems $[44 \div 46]$.

The capitalization of marine algae biomass can be made either for therapeutic purposes based on the active compounds from the marine algae or by the capitalization of marine algae residue with obtaining fertilizers used in agriculture. The high interestfor marine algae capitalization has taken into consideration only the marine resources with a low pollution value. For this reason, it is necessary to have data on the content of pollutants existing in the coastal marine environment.

For marine water in 2018 the following concentrations were obtained: $\mathrm{Zn}>\mathrm{Pb}>\mathrm{Cu}>\mathrm{Cd}$ and in 2017 the order was different: $\mathrm{Zn}>\mathrm{Cu}>\mathrm{Pb}>\mathrm{Cd}$. Compared to the literature [37], in the Romanian seawater, there is an increase in $\mathrm{Cd}$ and $\mathrm{Pb}$ concentrations in the years 2018: for $\mathrm{Cd}$ ions $(0.568 \pm 0.101 \mu \mathrm{g} / \mathrm{g})$ and for Pb ions $(12.78 \pm 0.90$ $\mu \mathrm{g} / \mathrm{g})$ and 2017 for $\mathrm{Cd}$ ions $(0.551 \pm 0.07 \mu \mathrm{g} / \mathrm{g})$ and for $\mathrm{Pb}$ ions (12.93 \pm 0.074$)$. These values are higher compared to 2011 for $C d$ ions $(0.41 \pm 0.10 \mu \mathrm{g} / \mathrm{g})$ and for $\mathrm{Pb}$ ions $(8.05 \pm 3.57 \mu \mathrm{g} / \mathrm{g})$ and to 2012 for Cd ions $(2.72 \pm 1.79 \mu \mathrm{g} /$ g) and for Pb ions $(4.03 \pm 2.12 \mu \mathrm{g} / \mathrm{g})$, [ 40]. In 2018 and 2017 there were no significant differences between sampling areas considering the heavy metals concentrations in water ( $p>0.05$, one way ANOVA test). Along the littoral, the largest contamination of the marine water was in the areas where harbour activities take place (S 2 - Constanta-South harbour and S6 Mangalia harbour).

Heavy metals in sediments: The quality of sediments represents an indicator on the compounds and elements that contribute to water pollution. Sediment contamination and polluting agent transfer to the biota represents one of the most serious issues we are confronted with. Regarding sediments, organisms are exposed to a higher contamination risk represented by a point of entry in food. Sediment matter is comprised of geo-chemical elements, interchangeable ions, carbonates, reductants, organic matter, sulphites and waste. Table 2 presents heavy metal concentrations in sediments $\mu \mathrm{g} / \mathrm{g}$ wet weight (mean $\pm \mathrm{SD}$ ) from all harvesting stations.

The highest values in sediment are registered by $\mathrm{Cu}$ (19.886 \pm 1.31 in 2018 and $16.24 \pm 0.931$ in 2017). The next high values are registered by $\mathrm{Pb}(17.39 \pm 0.078$ in 2018) and $\mathrm{Zn} \mathrm{(16.25 \pm 1.75} \mathrm{in} \mathrm{2018).} \mathrm{Compared} \mathrm{with} \mathrm{2018,} \mathrm{in} 2017$ the concentrations for $\mathrm{Zn}(15.125 \pm 0.58)$ and $\mathrm{Pb}$ $(12.78 \pm 0.90)$ were lower. For sediments in 2017 the order of concentrations is $\mathrm{Cu}>\mathrm{Zn}>\mathrm{Pb}>\mathrm{Cd}$. In 2018, the highest values in the sedimentare recorded by the nexthigh values

Table 1

HEAVY METALS CONCENTRATIONS IN SEAWATER $\mu \mathrm{g} / L$ WET WEIGHT (MEAN $\pm s d$ ) FROM THE ROMANIAN COAST OF THE BLACK SEA (ALL HARVESTING STATIONS INCLUDED)

\begin{tabular}{|l|l|l|l|l|l|}
\hline $\begin{array}{l}\text { Heavy Metals in } \\
\text { seawater }\end{array}$ & Year & $\mathrm{Cd}$ & $\mathrm{Cu}$ & $\mathrm{Pb}$ & $\mathrm{Zn}$ \\
\hline Present study & 2018 & $0.568 \pm 0.101$ & $11.24 \pm 0.93$ & $12.78 \pm 0.90$ & $20.12 \pm 0.58$ \\
\hline Present Study & 2017 & $0.551 \pm 0.07$ & $16.258 \pm 0.93$ & $12.93 \pm 0.074$ & $21.17 \pm 1.0$ \\
\hline Study of Jitar et al. [37] & 2012 & $2.72 \pm 1.79$ & $3.06 \pm 1.43$ & $4.03 \pm 2.12$ & - \\
\hline Study of Jitar et al. [37] & 2011 & $0.41 \pm 0.10$ & $20.26 \pm 5.05$ & $8.05 \pm 3.57$ & - \\
\hline
\end{tabular}

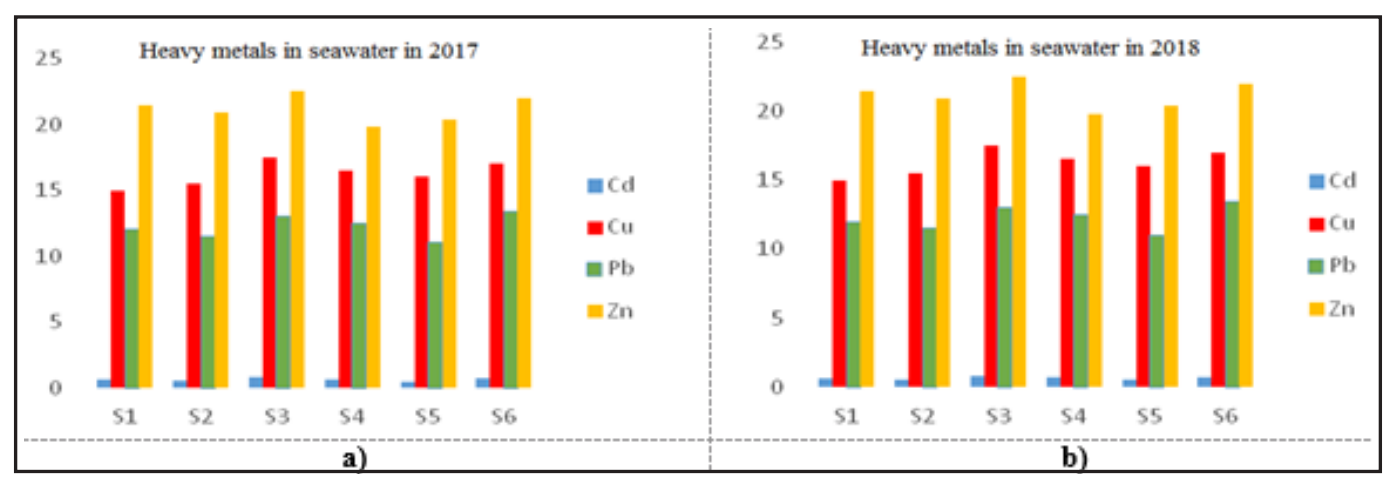

Fig. 2. Heavy metals concentrations in seawater $\mu \mathrm{g} / \mathrm{L}$ wet weight (mean $\pm \mathrm{SD}$ ) from the Romanian coast of the Black Sea (all harvesting stations included) in 2017 (a); in 2018 (b) 


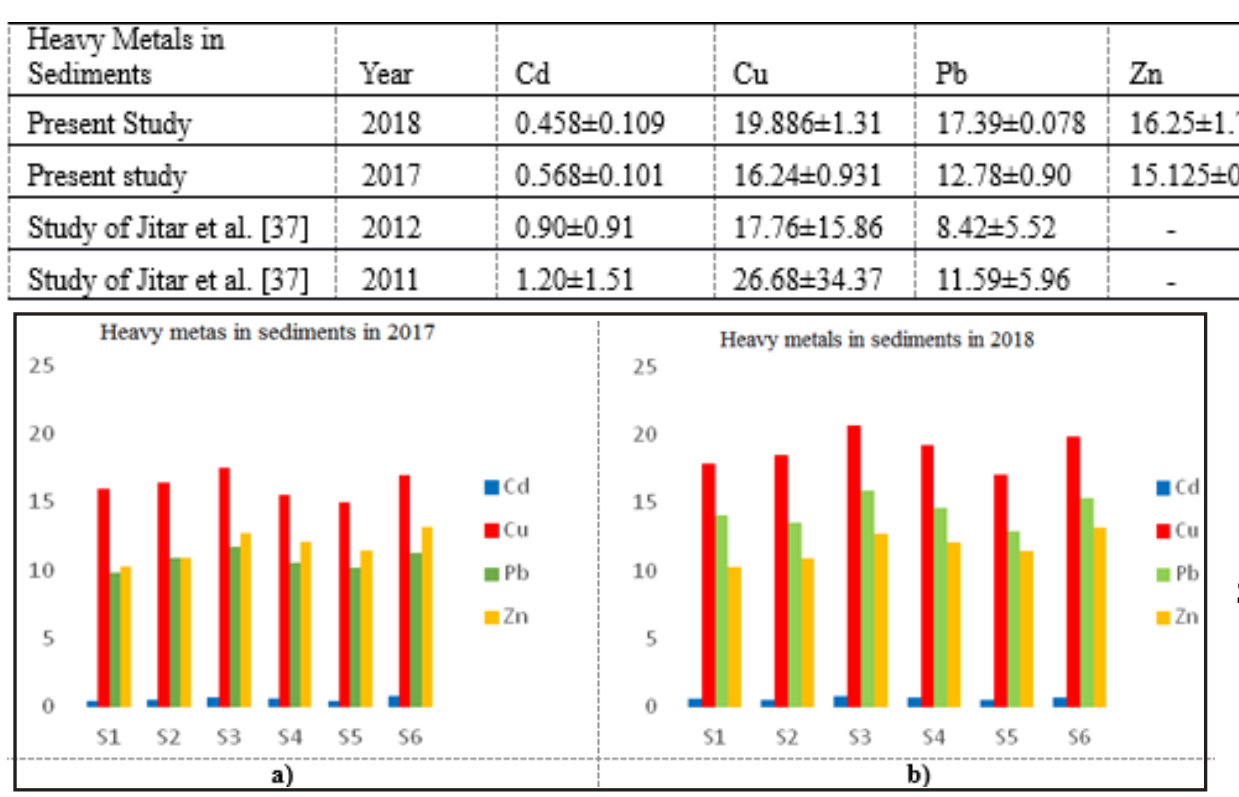

\begin{tabular}{|l|l|l|l|l|}
\hline Studied species $/ 2018$ & $\mathrm{Cd}$ & $\mathrm{Cu}$ & $\mathrm{Pb}$ & $\mathrm{Zn}$ \\
\hline Ulva spp. & $0.354 \pm 0.079$ & $12.83 \pm 1.33$ & $8.417 \pm 0.668$ & $19.301 \pm 0.445$ \\
\hline Cladophora spp. & $0.301 \pm 0.073$ & $11.99 \pm 1.11$ & $7.858 \pm 0.639$ & $18.785 \pm 0.521$ \\
\hline Enteromorpha spp. & $0.203 \pm 0.008$ & $10.916 \pm 1.122$ & $7.741 \pm 0.703$ & $18.116 \pm 0.647$ \\
\hline Ceramium rubrum & $0.3605 \pm 0.0759$ & $13.2 \pm 2.03$ & $8.858 \pm 0.574$ & $20.116 \pm 0.647$ \\
\hline Cystoseira barbata & $0.551 \pm 0.076$ & $13.783 \pm 1.096$ & $9.463 \pm 0.66$ & $19.848 \pm 0.56$ \\
\hline
\end{tabular}

\begin{tabular}{|l|l|l|l|l|}
\hline Studied species/2017 & $\mathrm{Cd}$ & $\mathrm{Cu}$ & $\mathrm{Pb}$ & $\mathrm{Zn}$ \\
\hline Ulva spp. & $0.418 \pm 0.101$ & $12 \pm 1.839$ & $6.417 \pm 0.668$ & $13.26 \pm 0.4$ \\
\hline Cladophora spp. & $0.398 \pm 0.097$ & $11.833 \pm 1.304$ & $5.858 \pm 0.639$ & $14.553 \pm 0.517$ \\
\hline Enteromorpha spp. & $0.07 \pm 0.07$ & $10.633 \pm 1.571$ & $7.741 \pm 0.703$ & $11.341 \pm 0.574$ \\
\hline Ceramium rubrum & $0.449 \pm 0.103$ & $13.2 \pm 2.031$ & $8.858 \pm 0.574$ & $10.55 \pm 0.962$ \\
\hline Cystoseira barbata & $0.426 \pm 0.074$ & $12.458 \pm 1.096$ & $8.463 \pm 0.66$ & $9.848 \pm 0.56$ \\
\hline
\end{tabular}

$\mathrm{Cu}>\mathrm{Pb}>\mathrm{Zn}>\mathrm{Cd}$. For sediments in 2017 are recorded the sediment concentrations by $\mathrm{Cu}(16.24 \pm 0.931 \mu \mathrm{g} / \mathrm{g})$, in comparison with $\mathrm{Zn}$ ions $(15,125 \pm 0.58 \mu \mathrm{g} / \mathrm{g}), \mathrm{Pb}(12.78$ $\pm 0.90 \mu \mathrm{g} / \mathrm{g})$ and $C d(0.568 \pm 0.101 \mu \mathrm{g} / \mathrm{g})$. In 2018 the highest values in the sediment are recorded by $\mathrm{Cu}$ ( 19.886 $\pm 1.31 \mu \mathrm{g} / \mathrm{g}), \mathrm{Pb}(17.39 \pm 0.078 \mu \mathrm{g} / \mathrm{g}), \mathrm{Zn}(16.25 \pm 1.75$ $\mu \mathrm{g} / \mathrm{g})$ and $C \mathrm{~d}(0.458 \pm 0.109 \mu \mathrm{g} / \mathrm{g})$. Compared with the data from the literature [37] for sediments at the Romanian seas there is also an increase in the years 2018 for the $\mathrm{Cd}$ concentrations $(0.458 \pm 0.109 \mu \mathrm{g} / \mathrm{g})$ and for $\mathrm{Pb}$ concentrations $(17.39 \pm 0.078 \mu \mathrm{g} / \mathrm{g})$ and in 2017 for $\mathrm{Cd}$ concentrations $(0.568 \pm 0.101 \mu \mathrm{g} / \mathrm{g})$ for $\mathrm{Pb}$ concentrations $(12.78 \pm 0.90 \mu \mathrm{g} / \mathrm{g})$ compared to the concentrations of $\mathrm{Cd}$ and $\mathrm{Pb}$ ions in 2011 and 2012 [40]. Figure 3 presents concentration annual variations in the six harvesting stations on the Romanian shore. It can be noticed that Cd registers very low values both for seawater and for sediment.

The highest values for $\mathrm{Cd}$ were registered in station $\mathrm{S} 6$, both in sea water $(0.65 \pm 0.1)$ and in sediment $(0.765 \pm$ 0.13 ). Taking into account sediment results in 2018, no major difference betw een areas was registered for $\mathrm{Zn}, \mathrm{Cd}$ and $\mathrm{Pb}$ (according to the Anova test $\mathrm{p}>0.05$ ), while $\mathrm{Cu}$ showed a significant difference between $S 3$ and $S 5$ $(p<0.05)$, S3 area registering higher values than S5. Taking into account sediment results in 2017, the Anova test $(p<0.05)$, showed significant differences for $\mathrm{Cu}$ between $\mathrm{S} 5$, compared to $\mathrm{S} 3$ and $\mathrm{S} 6$. For $\mathrm{Cd}, \mathrm{Pb}$ and $\mathrm{Zn}$ no major differences were registered. According to the Romanian legislation the heavy metals mean concentrations for sea water and for marine sediments were lower than the S3 in 2018.
Table 2

HEAVY METALS CONCENTRATIONS IN SEDIMENTS $\mu \mathrm{g} / \mathrm{g}$ WET WEIGHT (MEAN \pm sd) FROM THE ROMANIAN COAST OF THE BLACK SEA (ALL HARVESTING STATIONS INCLUDED)

Fig. 3. Heavy metals concentrations in sediments $\mu \mathrm{g} / \mathrm{g}$ wet weight (mean $\pm \mathrm{SD}$ ) from the Romanian coast of the Black Sea (all harvesting stations included), a) results in 2017; b) results in 2018

Table 3

HEAVY METALS CONCENTRATIONS IN ALGAE $\mu \mathrm{G} / \mathrm{G}$ WET WEIGHT (mean \pm sd) IN 2018 FROM THE ROMANIAN SHORE OF THE BLACK SEA (ALL HARVESTING STATIONS INCLUDED)

Table 4

HEAVY METALS CONCENTRATIONS IN ALGAE $\mu G / G$ WET WEIGHT (mean \pm sd) IN 2017 FROM THE ROMANIAN SHORE OF THE BLACK SEA (ALL HARVESTING STATIONS INCLUDED)

maximum concentrations allowed (MAC), values $(0.8 \mathrm{ppm}$ for cadmium, $40 \mathrm{ppm}$ for copper, $85 \mathrm{ppm}$ for lead) [47].

Heavy metals in marine algae: Algae are at the foundation of the trophic chain [48], their interaction with the environment being accomplished through chemical and biological processes including bioaccumulation, excretion, production of organic matter and discomposure. Due to the high ability to accumulate heavy metals, algae are often considered as a good bio-indicator [49]. Some species of algae can survive in polluted environments due to genetic mutations they have suffered. Tables 3 and Table 4 present heavy metal concentrations in algae $\mu \mathrm{g} / \mathrm{g}$ wet weight (mean \pm SD) in 2018 and 2017 from the Romanian shore of the Black Sea (all harvesting stations included).

Ulva spp. is an algae that floats and can fix on anything from hard rocks to sand and shells. It can be noticed that, among green algae, Ulva lactuca presents the highest concentrations for $\mathrm{Cd}$ in 2017 than 2018. Cladophora spp presents the lowest values for $\mathrm{Cd}, \mathrm{Pb}$ and $\mathrm{Zn}$ in 2017 than 2018. Red algae represented by Ceramium rubrum presents higher concentrations than green ones, as they also have a higher accumulation power. Fig. 4 presents the variation of Cd concentrations in the two years for all analysed algae (three green algae: Ulva lactuca, Cladophora spp, Enteromorpha spp, a red algae Ceramium rubrum and a brown algae Cystoseira barbata). All six harvesting stations were taken into account. For $\mathrm{Cd}$, the highest concentration is exhibited by the brown algae Cystoseira barbata in station 


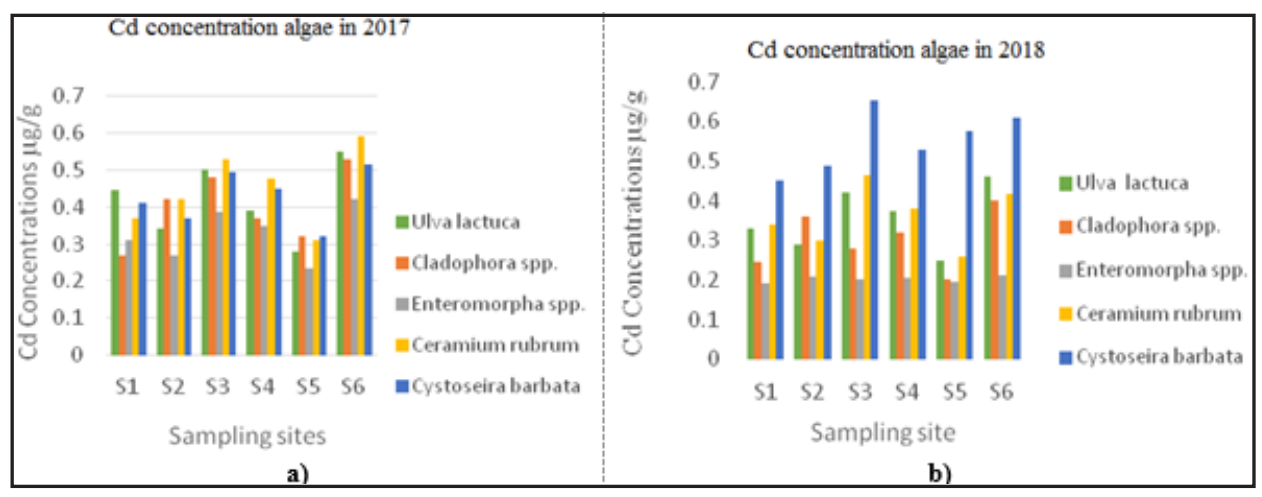

Fig. 4. Cd means concentrations in algae $\mu \mathrm{g} / \mathrm{g}$ wet weight from all sampling sites from the Romanian shore of the Black Sea in 2017 (a) and 2018 (b)
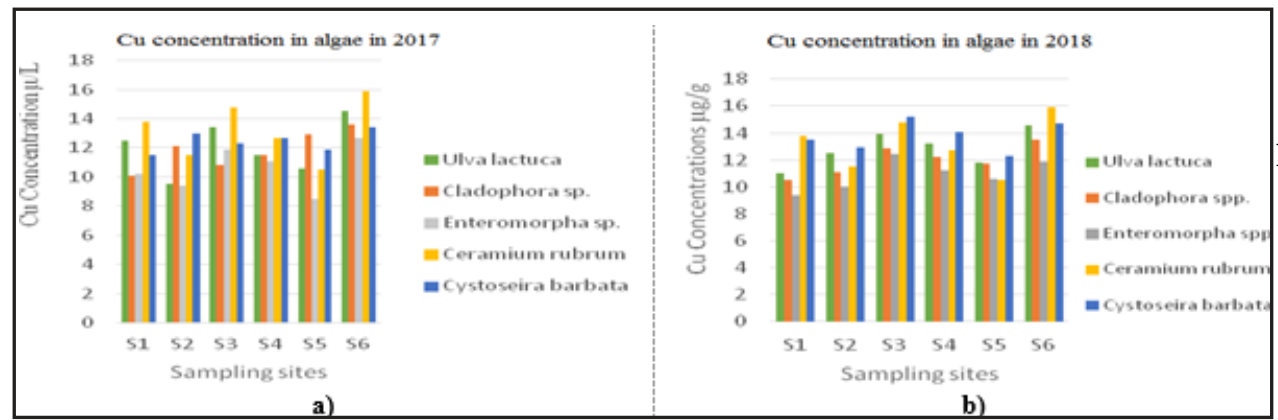

Fig. 5. Cu means concentrations in algae $\mu \mathrm{g} / \mathrm{g}$ wet weight from all sampling sites from the Romanian coast of the Black Sea in 2017(a) and 2018 (b)

Figure 5 presents variations in heavy metal concentrations in algae for all harvesting stations from the Romanian shore for $\mathrm{Cu}$ in the two years analysed. The red algae Ceramium rubrum and Ulva lactuca also, exhibits the highest $\mathrm{Cu}$ concentration in $\mathrm{S} 6$ during both years. In 2018, Cystoseira barbata exhibits lower values compared to 2017.

Figure 6 presents variations in mean $\mathrm{Pb}$ concentrations for all harvesting stations. In 2018, Cystoseira barbata and Ceramium rubrum registered the highest values for $\mathrm{Pb}$. In 2017, Ceramium rubrum overpassed $\mathrm{Pb}$ concentrations found in the other algae. In 2018, Pb accumulation was higher than in 2017.

Figure 7 presents variations in concentrations for $\mathrm{Zn}$ in all studied algae and for all harvesting stations in 2017 and 2018. In 2018 registers high values for $Z n$ in all algae and in all stations. However, 2017 is a bit different. The highest

values for Zn were registered for Ulva lactuca, followed by another green algae - Cladophora spp. The lowest values were registered by Cystoseira barbata.

\section{Bioaccumulation of heavy metal concentrations in algae with potential risks}

From environmental and health perspective, it is also important to determine potential risk assessment of bioaccumulation of heavy metals in marine algae for marine fauna and human health. For seaweed samples there are accumulations in the order of $\mathrm{Zn}>\mathrm{Cu}>\mathrm{Pb}>\mathrm{Cd}$. To prevent these damages, it is necessary to develop management systems of pollutants and to evaluate their bioaccumulation factors in tissues to keep under control the risk assessment systems. This information and provide a better identification of hazards, data from research laboratories, fate and effects on humans health and
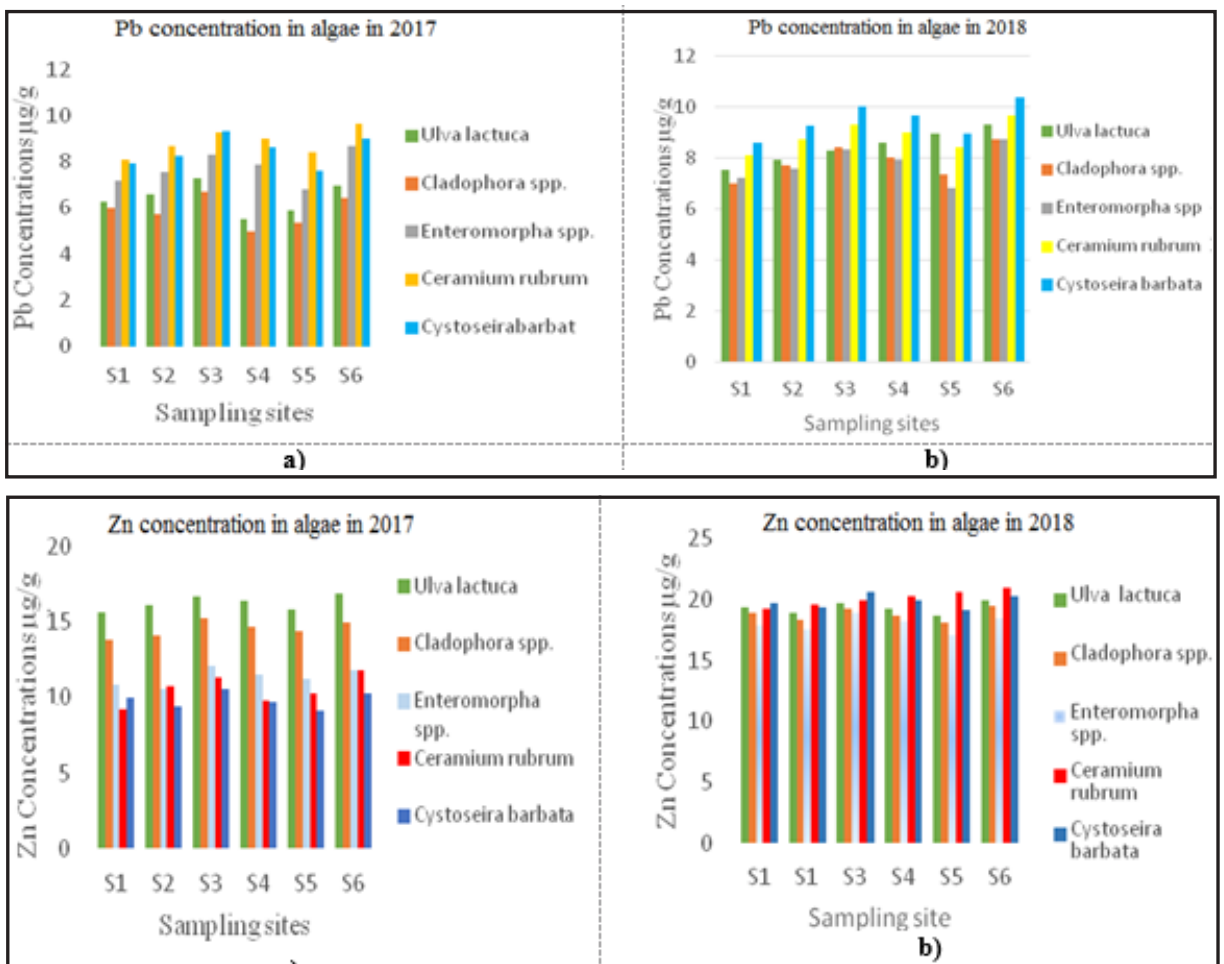

a)

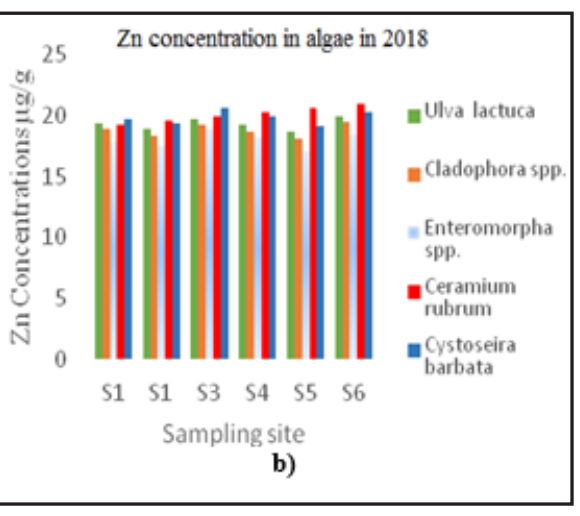

http://www.revistadechimie.ro
Fig.6. $\mathrm{Pb}$ means concentrations in algae $\mu \mathrm{g} / \mathrm{g}$ wet weight from all sampling sites from the Romanian coast of the Black Sea in 2017 (a) and 2018(b)

Fig.7 Zn means concentrations in algae $\mu \mathrm{g} / \mathrm{g}$ wet weight from all sampling sites from the Romanian coast of the Black Sea in 2017 (a) and 2018 (b) 
Table 5

BIOACCUMULATION FACTORS BCF ${ }_{\text {water }}$ AND BCF $_{\text {sed }}$ FOR Cd, Cu, Pb AND Zn IN THE STUDIED ALGAE FROM THE ROMANIAN COAST OF THE BLACK SEA BIOTA

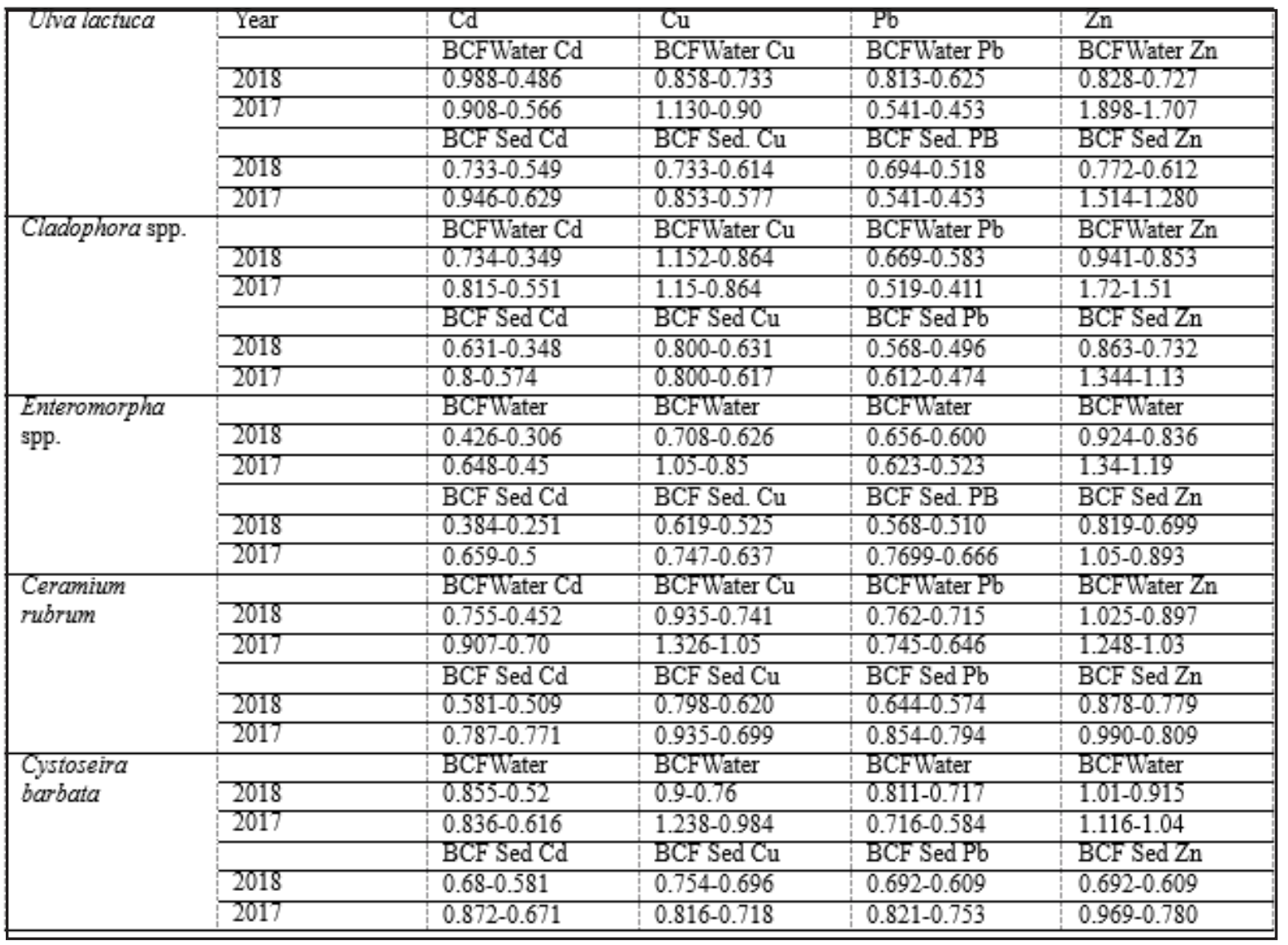

environment is useful. Heavy metal accumulation in algae is highlighted by the bioaccumulation factor.

From the analysis of the bioaccumulation factors, it can be noticed that seawater algae accumulate heavy metals from seaw ater and sediment ( confirmed by $\mathrm{BCF}_{\text {water }}>1$ or $\left.\mathrm{BCF}_{\text {sed }}>1\right)$. Consequently, the green algae Ulva lactuca accumulated, $\mathrm{Cu}$ from seawater with $\mathrm{BCF}_{\text {water }}=1.13>$ 1 (in 2017) and $\mathrm{Zn}$ from water with $\mathrm{BCF}_{\text {water }}=1.898-1.707$ $>1$ (in 2017) and from sediments, BCF $_{\text {sed }}^{\text {water }}=1.514-1.280>$ 1 (in 2017). The green algae Cladophora spp accumulated Cu from seawater with BCF $=1.152>1$, (in 2018) and $B C F_{\text {water }}=1.15>1$, (in 2017), and $\mathrm{Zn}$ from seawater with $\mathrm{BCF}_{\text {water }}^{\text {water }}=1.72-1.51>1$, (in 2017), and from sediments $\mathrm{BCF}_{\text {water }}=1.344-1.13>1$ (in 2017).

Enteromorpha accumulated in Cu from water with $\mathrm{BCF}=1.05>1$, (in 2017) and Zn from seawater with $\mathrm{BCF}^{\text {water }}=1.34-1.19>1$, (in 2017) and from sediments with $\mathrm{BCF}_{\text {sed }}^{\text {water }}=1.05>1$ (in 2017). The red algae Ceramium rubrum accumulated $\mathrm{Cu}$ from water with $\mathrm{BCF}_{\text {water }}=1.326-$ $1.05>1$ (in 2017) and $\mathrm{Zn}$ in both years from water with $\mathrm{BCF}_{\text {water }}=1.025>1$ (in 2018) and with $\mathrm{BCF}_{\text {water }}=1.248$ $1.03>^{\text {water }} 1$ (in 2017).

The brown algae Cystoseira barbata accumulated $\mathrm{Cu}$ from water with $\mathrm{BCF}_{\text {water }}=1.238>1$ (in 2017) and $\mathrm{Zn}$ from sea water with $B C F$ later $=1.01>1$ (in 2018) and with $\mathrm{BCF}_{\text {water }}=1.116-1.04>1$ ( $\mathrm{in}$ 2017). The data obtained is in line with literature on the matter, which has evidenced that green algae are considered as good indicators of heavy metal environment contamination. According to a study performed on Black Sea macroalgae on the Bulgarian coast between1996-2004, [27], heavy metal concentrations were higher in green algae, outlining the fact that these organisms have a high accumulation ability. There are studies that show that red algae tend to accumulate heavy metals (with the exception of iron) in higher concentrations than other algae [38]. Environmental pollution with its health impacts is a key issue for a sustainable environment. Sustainability has become a broad term that can be applied in almost every aspect of life on Earth, locally or globally and over various periods of time. Coastal areas of the world's seas and oceans are polluted with different pollutants from both technological and other sources of socio-human activities.

\section{Conclusions}

The current study represents a part of the monitoring activity of heavy metal contamination levels in sea water, sediments, and algae that can be found alongside the Romanian Black Sea coast. The need to outline contamination levels has lead the research team to establish six areas of sample harvesting in area most influenced by contamination (harbour activities, the presence of purging stations or touristic activities).

Accumulation has been evidenced through the calculation of bioaccumulation factors in sea algae. In 2018 and 2017, sea water concentrations did not show significant differences between the areas chosen for harvesting. Sediment concentration showed significant differences between areas for $\mathrm{Cu}$, especially in the areas influences by harbour activity in Constanta and Mangalia.

Algae accumulated more $\mathrm{Zn}$ and $\mathrm{Cu}$, followed by $\mathrm{Pb}$ and $\mathrm{Cd}$. BCF was higher in algae for $\mathrm{Cu}$ and $\mathrm{Zn}$. From the results obtained, the highest accumulation, as evidenced by the highest $\mathrm{BCF}_{\text {water }}$ was registered by the green Ulva lactuca algae for $\mathrm{Zn}$, from water and sediments, followed by the red algae Ceramium rubrum and Cystosera barbata. At shallow depths, heavy metal concentration is majorly influenced by the polluting factor in each area on the Romanian Black Sea coast. 
The capitalization of marine algae biomass can be done either for therapeutic purposes based on active compounds in marine algae, or by harvesting seaweed residues with the use of fertilizers used in agriculture. The high interest in harnessing marine algae has only taken into account marine resources with a low pollution value.

Acknowledgments: The authors would like to express appreciation for the financial support of the Romanian Ministry of Research UEFISCDI, for Complex Project no. 85 PCCDID 2018, Acronym INOBIOMAR, Projectcode PN-III-P1-1.2-PCCDI-2017-0701.

\section{References}

1.LAZAR, L., Contributii la cunoasterea si evaluarea fenomenului eutrofizarii in apele marine costiere romanesti, Ed. Exponto, Constanta, 2017, p. 11- 57.

2.SIRBU, R., STANCIU, G., CADAR, E., TOMESCU, A., CHERIM, M., Rev. Chim.(Bucharest), 70, no. 3, 2019, p. 835-842.

3.STANCIU, G., LUPSOR, S., TOMESCU, A., SIRBU, R., Rev. Chim.(Bucharest), 70, no. 2, 2019, p. 373-377.

4.TOMESCU, A., TOMESCU, C., L., BREZEANU, D., et al., 3-th SGEM Conference on Social Sciences and Arts, Bulgaria, II, 2016, P. 215-222. 5.GORUR, K.F., KESER, R., AKCAY, N., DIZMAN, S., Chemosp., 87, 2012, p. 356-61.

6.SIRBU, R., TOMESCU, A., JURJA, S., et al., 15-th SGEM Conference, Proceedings, Bulgaria, 1, 2015, p. 567-574.

7.CHERIM, M., SIRBU, R., TOMESCU, A., POPA,M., F., CADAR, E., Mat. Plast., 56, no. 1, 2019, p. 179-185

8. ${ }^{* * *}$ Commission E. Directive 56/EC - EU, Marine Strategy Framework Directive, 2008.

9.SIRBU, R., NEGREANU-PIRJ OL, T., PARIS, S., NEGREANU-PIRJ OL, B.S., JURJA, S., TOMESCU, A., - 14-th SGEM Conference Proceedings, Bulgaria, I, 2014, 381-388.

10.ZAHARIA, T., SIRBU, R., NICOLAEV, S., MICU, D., OCEANS - IEEE Conference Proceedings, 1-5, 2007, p. 147-152.

11.TOMESCU, A., SIRBU, R., STANCIU, G., et al., Envir. Prot. Ecol., 15, No. 1, 2014, P.303-308.

12.SIRBU, R., ZAHARIA, T., BECHIR, A., LILIOS, G., NICOLAEV, S., Envir. Prot. Ecol., 13, no 1, 2012, p. 190-197.

13.SIRBU, R., ZAHARIA, T., MAXIMOV, V., BECHIR, A., MARIS, M., NEGREANU-PIRJOL, B., MARIS, D.A., NEGREANU-PIRJ OL, T., LECA, M., CADAR, E.M., STOICESCU, R.M., MOCANU, L., JURJA, S., Envir. Prot. Ecol., 11, No 2, 2010, p. 654-665.

14.BECHIR, A., SIRBU, R., PACURAR, M., PODARIU, A.C., MONEA, M., BECHIR, E.S., GHERGIC, D.L., Rev. Chim. (Bucharest), 65, no. 3, 2014, p. 362-368.

15.SIRBU, R., MUSTAFA, A., TOMESCU, A., STANCIU, G., CADAR, E., Mat. Plast., 56, no. 1, 2019, p. 148-155.

16.PATTEE, O.H., DEBORAH, J.P., Handbook of ecotoxicology, Sec. Ed., Lewis Publishers, 2003, p. 373-408.

17.TAO, Y., YUAN, Z., XIAONA, H., WEI, M., Ecotoxi.Envir. Safety, 81, 2012, p. 55-64.

18. DEACONU (STANESCU), L.F., Rev. Chim.(Bucharest), 65, no.9, 2014, p. 1096 - 1102.

19.*** Commission Regulation (EC) No 1881, Offic. J. E U., 2006.

20.ERIMIA, C.L., SIRBU, R., 14-th SGEM Proceedings Conference, Bulgaria, 3, 2014, p. 807-814.

21.GEYER, H.J ., RIMKUS, G.G., SCHEUNERT, I., KAUNE, A., SCHRAMM, K.W., KETTRUP, A., ZEEMAN, M., MUIR, D.C.G., HANSEN, L.G., MACKAY, D., Handbook of envir. Chem., Berlin/Heidelberg, Bernd Beek, ed. Springer- Verlag, 2000, 3-17.
22.COPAT, C., ARENA, G., FIORE, M., LEDDA, C., FALLICO, R., SCIACCA, S., FERRANTE M., Food Chem. Toxicol 53, 2013, 33-37.

23.J ITAR, O., TEODOSIU, C., NICOARA, M., PLAVAN, G., Envir. Eng. Manage J, 12, 2013, p. 271.OLMEDO, P., PLA, A., HERNANDEZ, A.F., BARBIER, F., AYOUNI, L., GIL, F., Envir. Int, 59, 2013, p. 63-72.

24.IONESCU, P., DEAK, G., DIACU, E., RADU V.M., Rev. Chim.(Bucharest), 67, no. 11, 2016, p. 2148-2150.

25.ROMERA, E., GONZALEZ, F., BALLESTER, A., BLAZQUEZ, M.L., MUNOZ J.A., Bioresour Technol, 98, 2007, p. 3344-53.

26.STREZOV, A., NONOVA, T., J Env. Radioact., 100, 2009, p. 144-50.

27.OLGUIN, E.J ., SANCHEZ-GALVAN, G., New Biotec., 30, No. 1, 2012, p. 9-14.

28.IU, H.C., YOU, C.F., HUANG, B.J., HUH, C.A., Mar. Pollut. Bull., 73, 2013, p.37-46.

29.YIGITERHAN, O., MURRAY, J.W., TUGRUL, S., Mar. Chem, 126, 2011, 207-28.

30.ERGUL, H.A., TOPCUOGLU, S., OLMEZ, E., KIRBASOGLU, C., Scien. Res.,78, 2008, p. 396-402.

31.BORAN, M., ALTINOK, I., Turk J. Fish Aquat. Sci., 10, 2010, p. 56572.

32.BAKAN, G., BOKE-OZKOC, H., Int J Environ Stud., 64, 2008, p. 4557.

33.CEVIK, U., DAMLA, N., KOBYA, A.I., BULUT, V.N., DURAN, C., DALGIC, G., BOZACl, R., J Hazard Mater; 160, 2008, p. 396-401.

34.BOZCAARMUTLU, A., SAPMAZ, C., AYGUN, Z., ARINC, E., Mar. Env. Res, 67, 2009, p. 167-76.

35.NISBET, C., TERZI, G., PILGER, O., SARAC, N., Kafkas Univ Vet. Fak Derg. 16, No. 1, 2010, p. 119-125.

36.BAT, L., SEZGIN, M., USTUN, F., SAHIN, F., Turk J Fish Aquat. Sci, 12, 2012, p. 371-376.

37.CADAR, E., MUSTAFA, A., TOMESCU, A., CHERIM, M., J. Scien. Arts, 42, No. 1, 2018, p. 255-264.

38.ROMEO, M., FRASILA, C., BARELLI-GNASSIA, M., DAMIENS, G., MICU, D., MUSTATA, G., Water. Res., 39, 2005, p. 596-604.

39. JITAR, O., TEODOSIU, C., OROS, A., PLAVAN, G., NICOARA, M., New Biotec., 32, No. 3, 2015, p. 369-378.

40.MARCOVECCHIO, J.E., BOTTE, S.E., FREIJE R.H., Handbook of Water Anal. Sec. Ed. New York: CRC Press Taylor \& Francis Group, 2007, p. 275-311.

41.VRHOVNIK, P., ARREBOLA, J.P., SERAFIMOVSKI, T., DOLENEC, T., SMUC, N.R., DOLENEC, M., MUTCH, E. Environ. Pollut, 180, 2013, p. 92-100.

42.SIJ M, D.T.H.M., HERMES J.L.M., The Handbook of Envir. Chem, Berlin Heidelberg: Bernd Beek, ed. Springer-Verlag, 2000, p. 167-95. 43.SANCHEZ, W., EGEA, E., Environ. Sci. Pollut. Res. 25, 2018, p. 60856086.

44.IACOB, A., SIN, A., MOCAN, S., ORMENISAN, A., COMANEANU, R.M., HANCU, V., FULOP, E., TILINCA, M., Rev Chim. (Bucharest), 67, no. 10,2016, p. 2022-2027

45.SAMASCA, G., SUR, G., LUPAN, I., TILINCA, M,. DELEANU, D., Centr Eur J Immunol, 39, No 3, 2014, p. 396-399

46.*** Order no. 161 / Min. Envir. and Water Manag.Romanian Legislation, 2006.

47.MARIN, O.A., TIMOFTE, F., The Atlas of Macrophytes on the Romanian Seaside, Constanta, Boldas Ed., 2011, p. 27-40.

48.TOPCUOGLU, S., GUVEN, K.C., KIRBASOGLU, C., GUNGOR, N., UNLU, S., YLMAZ, Y.Z., Bull. Envir. Contam. Toxicol; 67, 2001, p. 288294.

Manuscript received: 21.01.2019 